\section{新赤色長残光蛍光体 \\ New Red Long Persistence Phosphor}

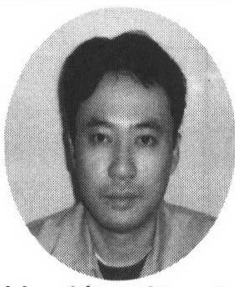

村 嵉 嘉 典 Yoshinori Murazaki

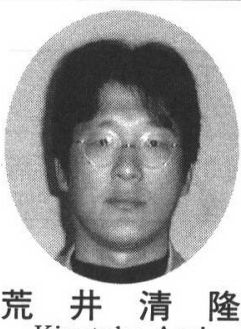
Kiyotaka Arai

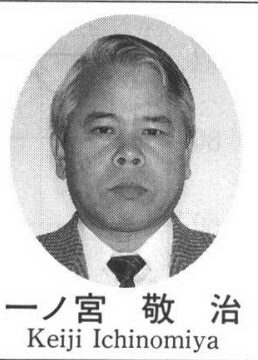

Keiji Ichinomiya

\section{1.はじめに}

長残光蛍光体は夜光塗料の一種である。従来，夜光塗 料といわれていた物質には自発光叙料と蓄光 (長残光蛍 光体）塗料の 2 種がある. 自発光塗料は, その励起工ネ ルギーを外部から求めず，それ自体に含まれる放射性物 質の放射エネルギーによって，常時一定の発光を呈する ものである. 蓄光塗料（長残光蛍光体）は太陽光や蛍光 灯などの外部エネルギーにより励起され，励起停止後に 暫時光エネルギーとして放出する物質である11. 本稿で は, 長残光蛍光体の現状と新しく開発した赤色長残光蛍 光体について述べる.

\section{2. 長残光蛍光体の現状}

長残光蛍光体は 1000 年も昔に日本人が造ったと想像 される話が中国の記録に残っている．工業的に製造，利 用されるようになったのは, 20世紀に入ってからであり， 主として軍事用途に利用されていた ${ }^{1)}$ 。その後数十年に わたり, 実用化された主要な長残光蛍光体は硫化物系の みであった2)(表 1 ).

近年ようやく，従来の長残光蛍光体の残光特性および 耐候性を大きく上回る，表 2 のアルミン酸塩を母体とす

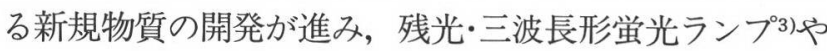
残光性タイル4)などの新たな商品展開が始まった。しか しながら，これらの新長残光蛍光体はすべて黄緑色の $530 \mathrm{~nm}$ より短波長域であり, 長波長域（赤色）長残光蛍 光体の出現が求められていた。

\section{3. 新赤色長残光蛍光体とその特性}

従来の赤色長残光蛍光体としては硫化物系の $\mathrm{CaS}$ ：Eu，Tm（ピーク波長650nm）がある。この物質

表 1 硫化物系長残光蛍光体の残光輝度（励起は $D_{65}$ 蛍光 ランプ1000 Ix 5 分間)

\begin{tabular}{|c|c|c|c|c|c|}
\hline & \multirow[t]{2}{*}{ 発光色 } & \multirow{2}{*}{$\begin{array}{l}\text { 発光ピーク } \\
\text { 波長(nm) }\end{array}$} & \multicolumn{2}{|c|}{$\begin{array}{l}\text { 残光輝度 } \\
\left(\mathrm{m} \mathrm{cd} / \mathrm{m}^{2}\right)\end{array}$} & \multirow{2}{*}{$\begin{array}{c}\text { 残光時間 } \\
\text { (min.) }\end{array}$} \\
\hline & & & 10分後 & 60分後 & \\
\hline CaSrS:Bi & 青 & 450 & 5 & 0.7 & 約 90 \\
\hline $\mathrm{ZnS}: \mathrm{Cu}$ & 黄緑 & 530 & 45 & 2 & 約 200 \\
\hline $\mathrm{ZnS}: \mathrm{Cu}, \mathrm{Co}$ & 黄緑 & 530 & 40 & 5 & 約500 \\
\hline CaS:Eu,Tm & 赤 & 650 & 1.2 & $\ldots$ & 約 45 \\
\hline
\end{tabular}

は残光輝度, 残光時間および化学安定性などにおいて実 用レベルに達していないのが現状であった。今回，われ われは300分以上の視認性を有し，かつ化学安定性に優 れた赤色長残光蛍光体を開発した。以下にその特性につ いて報告する。

\section{1 組成}

本蛍光体の組成は， $\mathrm{Y}_{2} \mathrm{O}_{2} \mathrm{~S} ： \mathrm{Eu}, \mathrm{Mg}$ ，Ti として表さ れる.母体結晶は酸硫化イットリウムで, Euのみで付活 したものはテレビ用赤色蛍光体として知られている5 われわれはトラップ形成のために不純物中心として, $\mathrm{Mg}$ と Ti を結晶中に導入することにより, 長残光蛍光 体として優れた特性を示すことを見い出した.

\section{2 発光と励起特性}

図 1 に365.0nm 励起による $\mathrm{Y}_{2} \mathrm{O}_{2} \mathrm{~S}: \mathrm{Eu}, \mathrm{Mg}, \mathrm{Ti}$ 蛍 光体の発光と励起スペクトルを示す． $625 \mathrm{~nm}$ にメイン ピークを持つ鮮やかな赤色発光である.

\section{3 残光特性}

表 3 に $\mathrm{Y}_{2} \mathrm{O}_{2} \mathrm{~S}$ ： $\mathrm{Eu}, \mathrm{Mg}$, Ti 蛍光体の残光特性を示 す。励起は $\mathrm{D}_{65}$ 常用蛍光ランプ $1000 \mathrm{~lx} 5$ 分である。表中 に例示してある $\mathrm{CaS}$ ： $\mathrm{Eu}, \mathrm{Tm}$ 赤色長残光蛍光体と比 較すると，本蛍光体は 10 分後で30倍以上の残光輝度で あった.また, 図 2 は $365.0 \mathrm{~nm}$ 発光ブラックライトを 1.0 $\mathrm{mW} / \mathrm{cm}^{2}$ の強度で15分間照射した後，残光輝度の経時 的変化を測定し，対数表示したものである。図中に例示 してある従来の $\mathrm{ZnS}: \mathrm{Cu}$ 緑色発光長残光営光体と比較 すると，本蛍光体は視感度が悪い赤色発光にもかかわら ず, 10 分後で 2 倍以上の残光輝度で, その残光は約 300 分 以上視認可能であった。

\section{4 耐久性}

実用化に際しては，蛍光体の耐久性も大きな要因とな る. そのため, 本蛍光体の熱・薬品・光に対する耐性を

表 2 新規長残光蛍光体の残光輝度（励起は $D_{65}$ 蛍光ラン プ1000 Ix 5 分間）

\begin{tabular}{|c|c|c|c|c|c|}
\hline & \multirow[t]{2}{*}{ 発光色 } & \multirow{2}{*}{$\begin{array}{l}\text { 発光ピーク } \\
\text { 波長 }(\mathrm{nm})\end{array}$} & \multicolumn{2}{|c|}{$\begin{array}{l}\text { 残光輝度 } \\
\left(\mathrm{m} \mathrm{cd} / \mathrm{m}^{2}\right)\end{array}$} & \multirow{2}{*}{$\begin{array}{c}\text { 残光時間 } \\
\text { (min.) }\end{array}$} \\
\hline & & & 10分後 & 60分後 & \\
\hline $\mathrm{CaAl}_{2} \mathrm{O}_{4}: \mathrm{Eu}, \mathrm{Nd}$ & 紫青 & 440 & 20 & 6 & 1000 以上 \\
\hline $\mathrm{Sr}_{4} \mathrm{Al}_{14} \mathrm{O}_{25}: \mathrm{Eu}, \mathrm{Dy}$ & 青緑 & 490 & 350 & 50 & 2000 以上 \\
\hline $\mathrm{SrAl}_{2} \mathrm{O}_{4}: \mathrm{Eu}, \mathrm{Dy}$ & 黄緑 & 520 & 400 & 60 & 2000 以上 \\
\hline $\mathrm{SrAl}_{2} \mathrm{O}_{4}: \mathrm{Eu}$ & 黄緑 & 520 & 30 & 6 & 2000 以上 \\
\hline
\end{tabular}




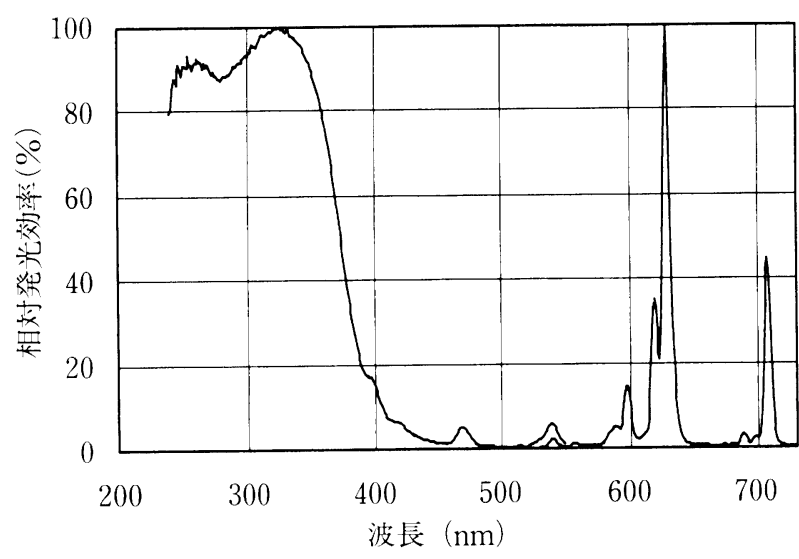

図 $1 \mathrm{Y}_{2} \mathrm{O}_{2} \mathrm{~S}$ : Eu, Mg, $\mathrm{Ti}$ の発光 (365.0nm 励起) と励起 スペクトル

表 $3 \mathrm{Y}_{2} \mathrm{O}_{2} \mathrm{~S}: \mathrm{Eu}, \mathrm{Mg}, \mathrm{Ti}$ 蛍光体の残光輝度（励起は $\mathrm{D}_{65}$ 蛍光ランプ1000 lx 5 分間)

\begin{tabular}{|c|c|c|c|c|c|}
\hline & \multirow{2}{*}{ 発光色 } & \multirow{2}{*}{$\begin{array}{l}\text { 発光ピーク } \\
\text { 波長 }(\mathrm{nm})\end{array}$} & \multicolumn{2}{|c|}{$\begin{array}{c}\text { 残光輝度 } \\
\left(\mathrm{m} \mathrm{cd} / \mathrm{m}^{2}\right)\end{array}$} & \multirow{2}{*}{$\begin{array}{c}\text { 残光時間 } \\
\text { (min.) }\end{array}$} \\
\hline & & & 10分後 & 60分後 & \\
\hline $\mathrm{Y}_{2} \mathrm{O}_{2} \mathrm{~S}: \mathrm{Eu}, \mathrm{Mg}, \mathrm{Ti}$ & 赤 & 625 & 40 & 3 & 300 以上 \\
\hline CaS:Eu,Tm & 赤 & 650 & 1.2 & $\cdots$ & 約45 \\
\hline
\end{tabular}

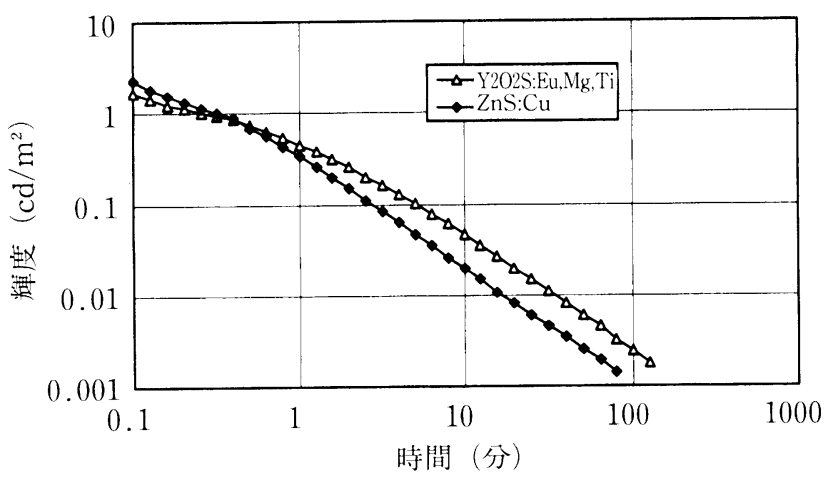

図2 $\mathrm{Y}_{2} \mathrm{O}_{2} \mathrm{~S}: \mathrm{Eu}, \mathrm{Mg}, \mathrm{Ti}$ と ZnS：Cu の残光特性（励起 は U.V.Lamp $1.0 \mathrm{~mW} / \mathrm{cm}^{2} 15$ 分間）

調查した。

\section{4 .1 耐熱性}

本蛍光体と現在実用化されている代表的な長残光蛍光 体を大気中で，各温度30分間加熱処理した後の相対残光 輝度維持率を図 3 に示す ${ }^{6)} .700^{\circ} \mathrm{C}$ 近くまでほとんど劣化

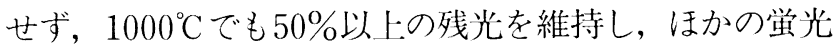
体と比較して，耐熱性に優れていることがいえる.

3.4 .2 而薬品性

$\mathrm{Y}_{2} \mathrm{O}_{2} \mathrm{~S}: \mathrm{Eu}, \mathrm{Mg}, \mathrm{Ti}$ 蛍光体を水, 5 \% 塭酸水溶液, $5 \% \mathrm{NaOH}$ 水溶液, 抢よびメ夕ノールの溶液に浸出させ たところ，どの溶液にもほとんど溶解せず，残光輝度も ほぼ維持した。

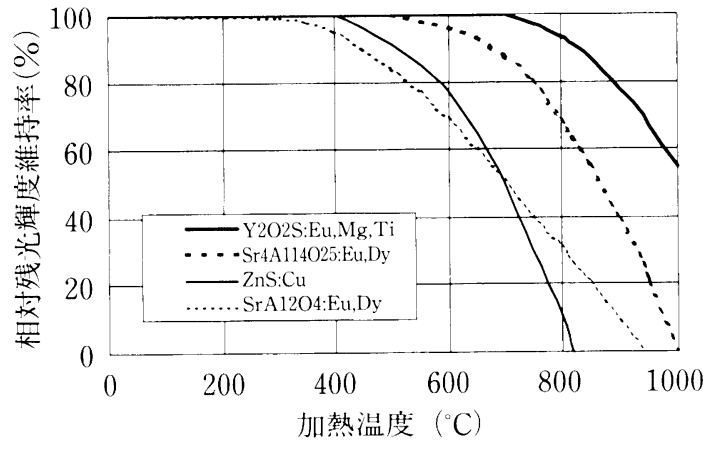

図 3 各長残光蛍光体の耐熱性

\section{4 .3 耐光性}

紫外線オートフェードメーターによる加速暴露テスト では，数年間の太陽光に相当する照射量で若干少化した が，現実的な使用に対しては，さほど問題にならない結 果であった。

\section{4.まとめ}

今回われわれが，新しく開発した赤色発光長残光蛍光 体は高輝度長残光であり，さらに耐熱性，耐薬品性，耐 光性にも優れている。このことは長残光ディスプレイも 青，緑，赤とフルカラー化が可能になり，防災安全，電 子機器などへの応用もさらなる増加を期待したい。

参考文献

（1）蛍光体同学会編：蛍光体ハンドブック，p.346（1987）

(2) 村山義彦：蓄光性材料セラミックス，32 No.1， p.41 (1997)

（3）長島由明，野村幸二：残光・三波長形蛍光ランプ「ホタルック」, 第262回鸴光体同学会講演予稿集, p.1（1996）

（4）尾石，澤口，尾畑：「長残光性上絵具の開発研究」，岐阜県陶磁器 試験場研究報告書, p.18（1997）

（5）蛍光体同学会編：蛍光体ハンドブック，p.11（1987）

（6）丙置，村崎，一／宮，Royce：「青緑色発光長残光発光体」，平成 8 年度照学全大, p.76（1996）

\section{著者紹介}

\section{村㟝 嘉典}

1967年生.1990年東京理科大学卒。現在，日曲化学工業㛦第一 部門日垔電子化学(侏技術部.

\section{荒井 清隆}

1960年生. 1984年徳島大学教育学部卒. 第一部門日車電子化学 株技術部.

\section{一ノ宮敬治}

1942年生. 1960年新野高校卒. 同年 4 月日曲化学工業(㑣人社., 現第一部門第一開発部部長兼日业電子化学(姝取締役技術部長 